Article

\title{
Ultrafiltration Fractionation of Bovine Hemoglobin Hydrolysates: Prediction of Separation Performances for Optimal Enrichment in Antimicrobial Peptide
}

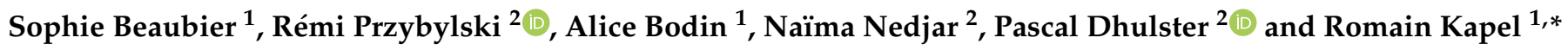 \\ 1 Laboratoire Réactions et Génie des Procédés, Université de Lorraine, UMR CNRS 7274, LRGP, \\ F-54500 Vandœuvre-lès-Nancy, France; sophie.beaubier@univ-lorraine.fr (S.B.); bodin.alice@gmail.com (A.B.) \\ 2 EA 7394-ICV—Charles Viollette Institute, University Lille, INRA, ISA, University Artois, \\ University Littoral Côte d'Opale, F-59000 Lille, France; remi.przybylski@polytech-lille.fr (R.P.); \\ naima.nedjar@univ-lille.fr (N.N.); pascal.dhulster@univ-lille.fr (P.D.) \\ * Correspondence: romain.kapel@univ-lorraine.fr
}

Citation: Beaubier, S.; Przybylski, R.; Bodin, A.; Nedjar, N.; Dhulster, P.;

Kapel, R. Ultrafiltration Fractionation of Bovine Hemoglobin Hydrolysates: Prediction of Separation Performances for Optimal Enrichment in Antimicrobial Peptide. Membranes 2021, 11, 73. https:// doi.org/10.3390/membranes11020073

Academic Editor: Karin Schroën

Received: 30 December 2020

Accepted: 17 January 2021

Published: 20 January 2021

Publisher's Note: MDPI stays neutral with regard to jurisdictional claims in published maps and institutional affiliations.

Copyright: () 2021 by the authors. Licensee MDPI, Basel, Switzerland. This article is an open access article distributed under the terms and conditions of the Creative Commons Attribution (CC BY) license (https:// creativecommons.org/licenses/by/ $4.0 /)$.

\begin{abstract}
Hydrolysis of bovine hemoglobin $(\mathrm{bHb})$, the main constituent of bovine cruor by-product, releases a natural antimicrobial peptide (NKT) which could present a major interest for food safety. To enrich this, tangential ultrafiltration can be implemented, but ultrafiltration conditions are mainly empirically established. In this context, the application of a simulation method for predicting the NKT yield and enrichment was investigated. Ultrafiltration performances were studied for decolored $\mathrm{bHb}$ hydrolysates at different degrees of hydrolysis ( $\mathrm{DH} ; 3 \%, 5 \%, 10 \%$ and 18\%) and colored hydrolysates $(3 \%$ and $5 \% \mathrm{DH})$ with 1 and $3 \mathrm{~kg} \cdot \mathrm{mol}^{-1}$ regenerated cellulose membranes. The simulation method helped to identify the most promising hydrolysate (in terms of NKT enrichment, yield and productivity) as the 3\% DH colored hydrolysate, and UF conditions (volumetric reduction factor of 5 and 3 with 1 and $3 \mathrm{~kg} \cdot \mathrm{mol}^{-1}$ membrane, respectively) for higher antimicrobial recovery. A maximal enrichment factor of about 29 and NKT purity of $70 \%$ in permeate were observed. The results showed that the antimicrobial activity was in relation with the process selectivity and NKT purity. Finally, this reliable method, applied for predicting the ultrafiltration performances to enrich peptides of interest, is part of a global approach to rationally valorize protein resources from various by-products.
\end{abstract}

Keywords: antimicrobial peptide; ultrafiltration; peptide separation; simulation; valorization

\section{Introduction}

In the food industry, bovine blood is an inevitable part of meat production and involves an environmental problem due its lack of harnessing [1]. Blood is rich in hemoglobin, a protein widely described as an excellent and emerging source of antimicrobial peptides [2]. One of them is particularly interesting in comparison with other antimicrobial peptides by means of specific features. Indeed, the $\alpha 137-141$ peptide (also called neokyotorphin or NKT) is a small peptide (653 Da, pI 10.5) composed of five amino-acids (Thr-Ser-LysTyr-Arg), while most antimicrobial peptides are composed of more than 20 amino acids for a molecular weight higher than $1500 \mathrm{Da}$ [3]. Moreover, NKT contains no hydrophobic residue, involving a particular and strong antimicrobial mechanism with no secondary structure unlike most antimicrobial peptides [4]. This peptide was previously described as a growth inhibitor of pathogenic bacteria commonly involved in the contamination phenomenon during the storage and distribution of food [5]. More recently, NKT derived from bovine hemoglobin showed antimicrobial and antioxidant properties as effective as the BHT activities after application into ground beef meat under refrigeration [6]. Therefore, this peptide could be a promising natural preservative. From this previous study, NKT appeared early during the pepsic hydrolysis of bovine hemoglobin $(\mathrm{bHb})$ and it was a final 
peptide, i.e., not cleaved into a smaller peptide. Indeed, its production can reach about $100 \mathrm{mg}$. $\mathrm{L}^{-1}$ after $24 \mathrm{~h}$, with a decreasing production rate after $30 \mathrm{~min}$ when more than $67 \%$ of NKT has been produced. Peptide enrichment from bHb could be influenced by the presence of the haem, responsible for the red color of bHb [7]. Haem also showed an increase in the bitterness of the final product and strong oxidative capacities which had a negative impact on the preservation of the hydrolysate and its bioactivity [8]. Consequently, some processes were developed to remove haem while the peptides were recovered and maintained in solution $[9,10]$. However, increasing the purity of the peptide is the key to obtaining better activity for a potential and attractive market product [11].

Tangential ultrafiltration is well known to improve a large spectrum of hydrolysate bioactivities because of bioactive peptide enrichments [12-18]. However, in the studies reported, the ultrafiltration (UF) conditions (membrane molecular weight cut-offs (MWCO), transmembrane pressure, hydrolysate concentration, volume reduction factor, tangential velocity, etc.) were empirically established after many runs of experiments implying fastidious procedures for the assessment of bioactivity. Some authors showed that the yield and enrichment of micropeptide fractions could be monitored during UF by analytical size exclusion chromatography (SEC) [19,20]. Based on these results, Kapel et al. [21] proposed a simulation method to predict the yield and enrichment of a targeted bioactive peptide in a UF permeate compartment. The simulation method, based on solute mass balance equations, only requires a SEC chromatogram and the protein aminogram. This method was validated with success with an alfalfa white protein hydrolysate, containing an antihypertensive peptide in a single UF operating condition.

In this article, the simulation method was applied to predict the performances of UF for the NKT yield and enrichment of decolored $\mathrm{bHb}$ hydrolysates at different degrees of hydrolysis $(3 \%, 5 \%, 10 \%$ and $18 \% \mathrm{DH})$ and in colored hydrolysates $(3 \%$ and $5 \%)$ with 1 and $3 \mathrm{~kg} \cdot \mathrm{mol}^{-1}$ regenerated cellulose membranes. Then, the most promising trade-offs in terms of NKT enrichment, yield and productivity were implemented and the antimicrobial activities of the fractions obtained were evaluated in four microorganisms known to cause food safety problems (Micrococcus luteus, Listeria innocua, Escherichia coli and Salmonella enteritidis). Eventually, the antimicrobial activities versus the NKT purity of the fractions were discussed.

\section{Materials and Methods}

\subsection{Material}

HPLC grade acetonitrile was purchased from Fisher Scientific (Waltham, MA, USA). Trifluoroacetic acid was obtained from Arcos Organics (Waltham, MA, USA). Sodium hydroxide pellets were supplied by Carlo Erba Reactifs (Val de Reuil, France). Bovine hemoglobin $(\mathrm{bHb})$ and porcine pepsin were from Sigma Aldrich (Saint Quentin Fallavier, France). The mean molar mass by amino acid $\overline{M W_{a a}}$ and the mean molar extinction coefficient by amino acid $\overline{\varepsilon_{a a}}$ of the bHb was calculated from its primary sequence as $115 \mathrm{~g} \cdot \mathrm{mol}^{-1}$ and $987 \mathrm{~L} \cdot \mathrm{mol}^{-1} \cdot \mathrm{cm}^{-1}$, respectively.

\subsection{Hydrolysate Preparation}

A stock solution was prepared by adding dried bHb (Sigma Aldrich, Saint Quentin Fallavier, France) into $100 \mathrm{~mL}$ of ultrapure water and the precise bHb concentration was measured by the Drabkin method [22] after centrifugation (30 $\mathrm{min}, 4000 \mathrm{tr} \cdot \mathrm{min}^{-1}$ ) to remove the insoluble part. The stock solution was diluted to obtain the required concentration of $1 \%(w / v)$. Hydrolysis was carried out at $\mathrm{pH} 3.5$ and under constant temperature $\left(23^{\circ} \mathrm{C}\right)$, using pepsin from porcine gastric mucosa (EC 3.4.23.1, 3200-4500 units. $\mathrm{mg}^{-1}$ protein) with an enzyme/substrate ratio of $1 / 11$ (mole/mole). The hydrolyses were stopped by adding sodium hydroxide $(5 \mathrm{M})$ up to a final $\mathrm{pH}$ of 9.0 after 2.5 and $10 \mathrm{~min}, 3$ and $24 \mathrm{~h}$ corresponding to respective degrees of hydrolysis (DH) of 3, 5, 10 and 18\% [6], assessed by the ortho-phthaldialdehyde method [23]. These hydrolysates were identified as "whole hydrolysates", called "colored hydrolysates". A previous study showed that the presence 
of haem has a negative impact on the peptide transfer during the separation process using an ultrafiltration membrane [7]. The removal of haem consisted of slowly lowering the $\mathrm{pH}$ to a value of 4.7 with hydrochloric acid $\left(2 \mathrm{M}\right.$ at $\left.2 \mathrm{~mL} \cdot \mathrm{min}^{-1}\right)$. After $24 \mathrm{~h}$ at room temperature, the haem was totally precipitated, and the peptides were maintained in solution. Both phases were separated by centrifugation $\left(30 \mathrm{~min}, 4000 \mathrm{tr} \cdot \mathrm{min}^{-1}\right)$. In this paper, the hydrolysates without haem were called "decolored hydrolysates".

\subsection{Yield and Enrichment Simulation Methodology}

\subsubsection{Membrane Calibration}

The simulation of the evolution of the yield and enrichment during the UF is based on a membrane calibration equation [21]. This calibration was achieved by analyzing the UF permeate and retentate outlets in total recirculation mode by size exclusion chromatography (SEC). A value of retention $\left(R_{x}\right)$ was calculated for each point " $x$ " of the profile, as follows

$$
R_{x}=1-\frac{A_{p, x}}{A_{r, x}}
$$

with $A_{p, x}$ and $A_{r, x}$ as the absorbances of the point eluted at the time " $x$ " in permeate and retentate, respectively. Then, a molar weight value was associated based on its elution time and the SEC column calibration. The membrane calibration equation was yielded by linear regression of (R vs. $\log (\mathrm{MW})$ ) applied to each point " $\mathrm{x}$ ". The 1 and $3 \mathrm{~kg} \cdot \mathrm{mol}^{-1}$ membrane calibrations were achieved for each hydrolysate considered in the study at 3 bar of transmembrane pressure (TMP), a concentration of hydrolysate of $10 \mathrm{~g} \cdot \mathrm{L}^{-1}$ and a retentate flow rate of $0.1 \mathrm{~L} \cdot \mathrm{min}^{-1}$.

\subsubsection{Yield}

In UF, the yield $(\eta)$ of a solute " $\mathrm{i}$ " in the permeate compartment was given by Equation (2)

$$
\eta=\frac{\overline{C_{p, i}}}{C_{0, i}} \times\left(1-\frac{1}{V R F}\right)
$$

with $\overline{\mathrm{C}_{\mathrm{p}, \mathrm{i}}}$ and $\mathrm{C}_{0, \mathrm{i}}$ as the concentrations of the solute " $\mathrm{i}$ " in the permeate compartment and in the starting hydrolysate, respectively, and the volume reduction factor (VRF) calculated as $V R F=V_{0} / V_{R}$, with $V_{0}$ and $V_{R}$ being the initial volume and the volume in the retentate compartment.

The relative concentration of " $\mathrm{i}$ " can be deduced from the mass balance as follows:

$$
\frac{\overline{\mathrm{C}_{\mathrm{p}, \mathrm{i}}}}{\mathrm{C}_{0, \mathrm{i}}}=\frac{\mathrm{VRF}-\mathrm{VRF}^{R_{\mathrm{i}}}}{\mathrm{VRF}-1}
$$

The retentions of NKT $\left(\mathrm{MW}=653 \mathrm{~g} \cdot \mathrm{mol}^{-1}\right)$ with the $1 \mathrm{and} 3 \mathrm{~kg} \cdot \mathrm{mol}^{-1}$ membranes were 0.625 and 0.305 , respectively. These values were deduced from the membrane calibration equations obtained with the $\mathrm{bHb}$ decolored hydrolysate at $10 \% \mathrm{DH}(\mathrm{R}=0.7978$ $\times \log (\mathrm{MW})-1.621$, with $1 \mathrm{~kg} \cdot \mathrm{mol}^{-1}$ membrane, and $\mathrm{R}=1.055 \times \log (\mathrm{MW})-2.666$; with $3 \mathrm{~kg} \cdot \mathrm{mol}^{-1}$ membrane).

\subsubsection{Enrichment}

The enrichment $(\tau)$ of a solute " $\mathrm{i}$ " in the UF permeate compartment was given by Equation (4)

$$
\tau=\frac{\overline{\mathrm{C}_{\mathrm{p}, \mathrm{i}}}}{\mathrm{C}_{0, \mathrm{i}}} \times \frac{\sum \mathrm{C}_{0}}{\sum \overline{\mathrm{C}_{\mathrm{p}}}}
$$

with $\sum \mathrm{C}_{0}$ and $\sum \overline{\mathrm{C}_{\mathrm{p}}}$, the peptide concentrations of the starting hydrolysate and the permeate UF fraction, respectively.

The peptide concentrations in the permeate compartment $\overline{C_{p, i}}$ can theoretically be calculated for a given VRF applying Equation (3) to each peptide comprising the hy- 
drolysate. This supposes knowledge of every peptide molar weight and concentration in the hydrolysate, which is impossible for such complex mixtures. The originality of the simulation methodology consists of assessing the permeate peptide concentration from the hydrolysate SE-chromatogram. First, the UV signal of the chromatogram was converted into a concentration according to Kapel et al. [21]. Then, Equation (3) was applied to each point " $x$ " of the chromatogram to give a calculated permeate chromatogram. The retention $R$ value used for each chromatogram point was deduced from the elution time using the SE column and the membrane calibration. Eventually, this permeate chromatogram was integrated to give $\sum \overline{\mathrm{C}_{\mathrm{p}}}$ at any VRF.

\subsection{Ultrafiltration Experiments}

The ultrafiltration experiments were performed with regenerated cellulose UF membranes (MWCO of 1 and $3 \mathrm{~kg} \cdot \mathrm{mol}^{-1}$ with a surface of $88 \mathrm{~cm}^{2}$, Millipore, Burlington, Massachusetts, USA). The experiments were conducted on a Cogent $\mu$ Scale TFF system (Millipore) at room temperature $\left(22^{\circ} \mathrm{C}+/-2^{\circ} \mathrm{C}\right)$ and 3 bar of transmembrane pressure (under the critical TMP). The initial hydrolysate volume and concentration were $0.2 \mathrm{~L}$ and $10 \mathrm{~g} \cdot \mathrm{L}^{-1}$, respectively. The recirculation flow rate was $0.1 \mathrm{~L} \cdot \mathrm{min}^{-1}$. The permeate was collected after $20 \mathrm{~min}$ of total recycling (permeate and retentate outlets) to stabilize the polarization layer and the permeate flux. The UF experiments were stopped at a volume factor reduction (VRF) of 5 . The experiments were performed in triplicate for both operating modes. The membranes were washed and stored in $0.1 \mathrm{M} \mathrm{NaOH}$ (storage at $\left.4{ }^{\circ} \mathrm{C}\right)$.

\subsection{Hydrolysates and Fraction Reverse Phase HPLC Analyses}

The liquid chromatographic system consisted of a Waters 600E automated gradient controller pump module, a Waters Wisp 717 automatic sampling device and a Waters 996 photodiode array detector (Milford, USA). The methodology applied for the analysis and the peptide quantification was described in a previous paper [6]. Briefly, a standard curve was established by injections of standard NKT at concentrations ranging between 0 and $1 \mathrm{mg} \cdot \mathrm{mL}^{-1}$. The following Equation (5) was used to link the area under the peak of NKT from the chromatographic profile at $214 \mathrm{~nm}$ to its concentration in the sample

$$
\mathrm{C}_{\mathrm{NKT}}=4419.6 \times \mathrm{A}_{\mathrm{NKT}}
$$

with $\mathrm{C}_{\mathrm{NKT}}$ being the NKT concentration $\left(\mathrm{mg} . \mathrm{L}^{-1}\right)$ and $\mathrm{A}_{\mathrm{NKT}}$ being the area peak $(\mu \mathrm{V} . \mathrm{s})$.

The NKT purity (\%) was assessed as follows

$$
\text { NKT purity }(\%)=\frac{\mathrm{A}_{\mathrm{NKT}}}{\mathrm{A}_{\text {total }}} \times 100
$$

with $A_{N K T}$ being the area peak ( $\mu$ V.s) and $A_{\text {total }}$ being the total peptide area of the chromatogram ( $\mu$ V.s.s).

\subsection{Hydrolysates and Fraction SE-HPLC Analysis}

The $\mathrm{bHb}$ hydrolysates and the UF fractions were analysed by SEC using a Superdex peptide HR 10/300 column $(10 \times 300 \mathrm{~mm}$, GE Healthcare, Chicago, Illinois, USA) connected to a Shimadzu model LC20 system (Shimadzu Corporation, Kyoto, Japan). $50 \mu \mathrm{L}$ of sample were injected onto the column. The mobile phase consisted in water and acetonitrile in a $69.9 / 30$ proportion $(v / v)$ with $0.1 \%$ TFA $(v / v)$. Samples were eluted at a flow rate of $0.5 \mathrm{~mL} \cdot \mathrm{min}^{-1}$ and under a temperature of $35^{\circ} \mathrm{C}$. The UV signal was monitored at $214 \mathrm{~nm}$ using cells with an optical path of $1 \mathrm{~cm}$. The column was calibrated with 45 synthesized peptides from 220 to $1890 \mathrm{~g} \cdot \mathrm{mol}^{-1}$ eluted in the same conditions (the calibration equation was $\log (\mathrm{MW})=-0.082 . \mathrm{Tr}+5.382$, with $\mathrm{Tr}$, the elution time in $\mathrm{min})$. The chromatograms were exported in Excel spreadsheets and the absorbance signals were converted into concentrations using the methodology reported by Bodin et al. [24]. 
The chromatograms in concentrations were integrated to quantify the peptide concentrations in the UF permeate compartments and calculate the peptide molar weight cumulative frequency (in mass). The productivity was also calculated from the total peptide concentration in the UF permeate compartment. The membrane surface area used $\left(\mathrm{m}^{2}\right)$ and the ultrafiltration duration $(\mathrm{h})$ were considered, and the productivity was expressed in g.m $\mathrm{m}^{-2} \cdot \mathrm{h}^{-1}$.

\subsection{Neokyotorphin Relative Concentration Quantification by RP-HPLC/MS}

The experimental $\mathrm{C}_{\mathrm{p}} / \mathrm{C}_{0}$ values of NKT were determined by RP-HPLC/MS. The column used was a C18 Prosphere $(250 \times 21 \mathrm{~mm}, 5 \mu \mathrm{m}$ diameter beads $)$ provided by Alltech (Carquefou, France) connected to the Shimadzu model LC20 system. For the analysis, the column was kept at $35{ }^{\circ} \mathrm{C}$. A total of $10 \mu \mathrm{L}$ of sample was injected. For the elution, gradient of solvent A (water/acetonitrile in $94.9 / 5$ proportion $(v / v)$ with $0.1 \%$ TFA $(v / v)$ ) and solvent B (water/acetonitrile in $4.9 / 95$ proportion $(v / v)$ with $0.1 \%$ TFA $(v / v))$ was used. The starting condition was $100 \%$ A. A first slope was applied to reach $28 \% \mathrm{~B} / 72 \% \mathrm{~A}$ in $50 \mathrm{~min}$. Then, a second slope was applied to reach $48 \% \mathrm{~B} / 52 \% \mathrm{~A}$ in $20 \mathrm{~min}$. The column was finally washed with $100 \% \mathrm{~B}$ for $10 \mathrm{~min}$ and re-equilibrated in $100 \%$ A for $15 \mathrm{~min}$. The flowrate was $0.2 \mathrm{~mL} \cdot \mathrm{min}^{-1}$. The eluent was analysed on-line by electrospray ionization mass spectrometry (ESI-MS) (Shimadzu Corporation, Kyoto, Japan) in positive mode. The following operating parameters were used in TIC mode: mass scan $=50-2000 \mathrm{~m} / \mathrm{z}$, ion spray tension $=4.5 \mathrm{kV}$, heat block temperature $=200{ }^{\circ} \mathrm{C}$, drying gas flow $=15 \mathrm{~L} / \mathrm{min}$, scan speed $=2143$ mass units $/ \mathrm{s}$. Selected Ion Monitoring (SIM) mode was also used to monitor the targeted peptides. The integration values of NKT MS signal were integrated to assess the $\mathrm{C} / \mathrm{C}_{0}$ values in the UF samples.

\subsection{Evaluation of Antimicrobial Activity}

The antimicrobial activity was determined by measurement of the minimum inhibitory concentration (MIC) according to a previous study [25]. Briefly, the hydrolysates and the peptide fractions were tested against the growths of Gram-positive (Micrococcus luteus ATCC 4698 and Listeria innocua ATCC 33090) and Gram-negative bacteria (Escherichia coli ATCC 25922 and Salmonella enteritidis ATCC 13076), broadly described as inhibited by the bioactive peptides contained in the bHb hydrolysates [2]. A total of $20 \mu \mathrm{L}$ of strain preculture was inoculated into $10 \mathrm{~mL}$ of liquid Lysogeny Broth (LB) medium and the preculture was performed on a rotary shaker $\left(160 \mathrm{~min}^{-1}\right)$ at $37^{\circ} \mathrm{C}$ to obtain a standard cell concentration of $10^{6} \mathrm{CFU} \cdot \mathrm{mL}^{-1}$ (colony-forming unit). A total of $100 \mu \mathrm{L}$ of preculture was distributed in a microtiter plate well and added to $100 \mu \mathrm{L}$ of the peptide fraction or hydrolysate. Each peptide sample was tested at least in triplicate.

The absorbance of each well was read at $630 \mathrm{~nm}$ against the blank obtained before incubation by using a microplate absorbance reader ELx808 with the Gen 5 software (Biotek Instrument, Winooski, USA). MIC was the lowest peptide concentration that inhibited the strain growth after incubation $\left(24 \mathrm{~h}, 37^{\circ} \mathrm{C}\right)$ and was expressed in $\mu g_{\text {peptide }} \cdot \mathrm{mL}^{-1}$.

\section{Results and Discussion}

\section{1. bHb Hydrolysates Characterization}

Figure 1a shows the SEC chromatograms of bHb hydrolysates at 3\%, 5\%, 10\% and $18 \% \mathrm{DH}$ after haem removal by acid precipitation $\left(3 \% \mathrm{DH}_{\mathrm{dec}}, 5 \% \mathrm{DH}_{\mathrm{dec}}, 10 \% \mathrm{DH}_{\mathrm{dec}}\right.$ and $\left.18 \% \mathrm{DH}_{\mathrm{dec}}\right)$. An increase in the elution volume range of peptides with increasing $\mathrm{DH}$ was observed. This indicated a decrease in the peptide molar weights during the proteolysis. Figure $1 \mathrm{~b}$ shows that the median molar weight of the peptides decreased from 2600 to $1000 \mathrm{~g} \cdot \mathrm{mol}^{-1}$ from $3 \% \mathrm{DH}_{\mathrm{dec}}$ to $18 \% \mathrm{DH}_{\mathrm{dec}}$. This meant that the proteolysis followed a zipper-type mechanism. This is because, during the zipper-type proteolysis, the protein is fully hydrolyzed at the early stage of the reaction into a first set of intermediate peptides which are further hydrolyzed into final and smaller peptides at a higher degree of hydrolysis [26,27]. 

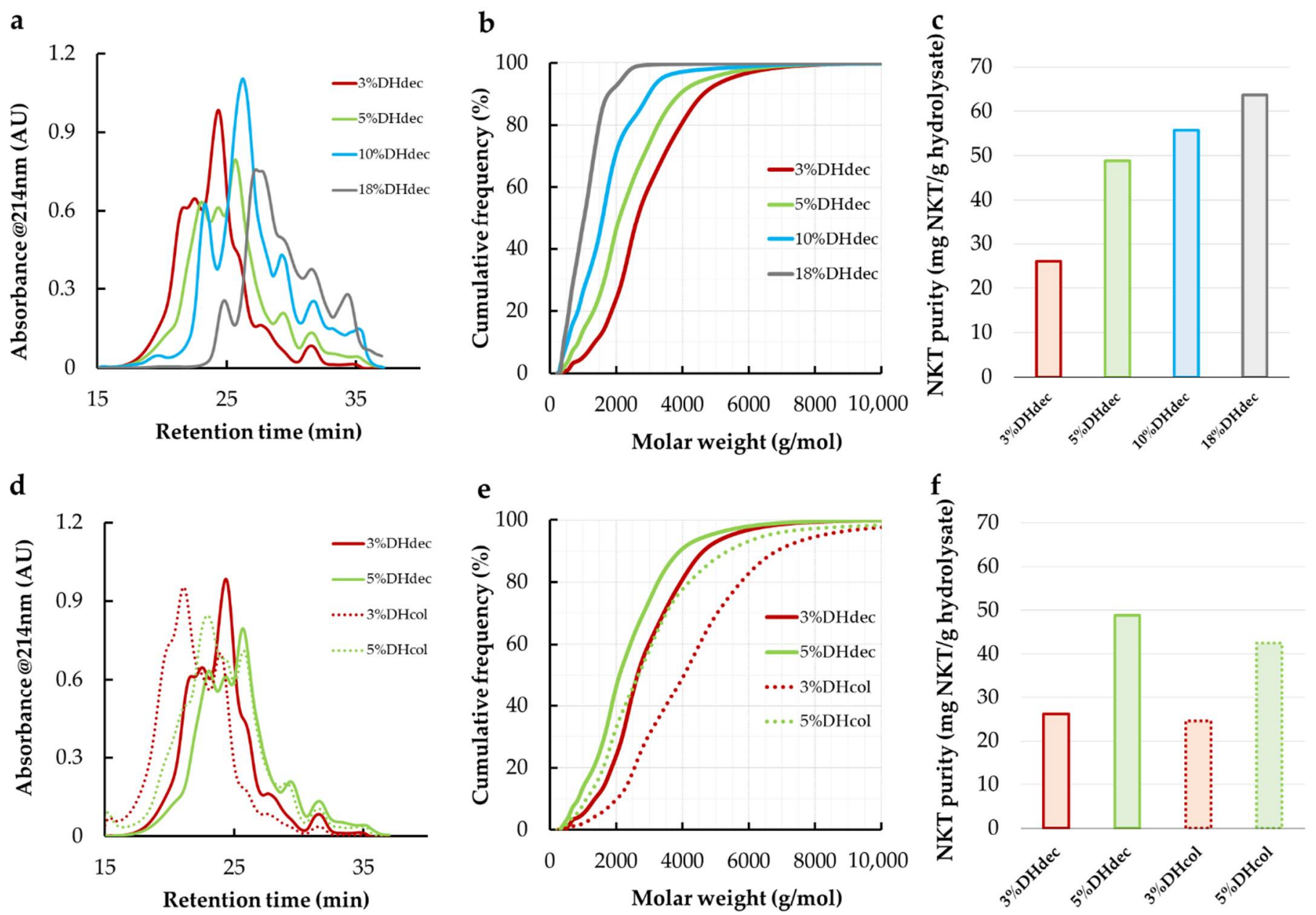

Figure 1. Size exclusion chromatograms at $214 \mathrm{~nm}$ of bovine hemoglobin hydrolysates (a,d); deduced peptide molar weights distributions (b,e) and natural antimicrobial peptide (NKT) purity $(\mathbf{c}, \mathbf{f})$. Letters $(\mathbf{a}-\mathbf{c})$ display data from 3\%, 5\%, 10\% and $18 \%$ DH decolored (dec) hydrolysates while (d-f) compare 3\% and 5\% DH hydrolysates decolored or colored (col).

The neokyotorphin (NKT) purity in the hydrolysates increased from $26.1 \mathrm{mg}$ NKT/g hydrolysate to $63.8 \mathrm{mg} \mathrm{NKT/g}$ in $3 \% \mathrm{DH}_{\mathrm{dec}}$ and $18 \% \mathrm{DH}_{\mathrm{dec}}$ (Figure 1c). The continuous increase in the NKT concentration during the proteolysis revealed that NKT is a final peptide produced at a relatively early stage of the proteolysis. This was also observed by others in a similar proteolysis condition [28]. Figure $1 \mathrm{~b}$ showed that $3 \% \mathrm{DH}_{\mathrm{dec}}$ contained $2.7 \%(w / w)$ of peptides having a molar weight inferior to NKT $\left(\mathrm{MW}_{\mathrm{NKT}}=653 \mathrm{~g} \cdot \mathrm{mol}^{-1}\right)$. This proportion raised up to $26.1 \%$ in $18 \% \mathrm{DH}_{\mathrm{dec}}$. Hence, despite the highest NKT purity, $18 \% \mathrm{DH}_{\mathrm{dec}}$ might not be the most appropriate hydrolysate for NKT enrichment by membrane separation. $3 \%$ and $5 \%$ DH hydrolysates without haem removal $\left(3 \% \mathrm{DH}_{\mathrm{col}}\right.$ and $5 \% \mathrm{DH}_{\text {col }}$ ) were also analyzed and compared to $3 \% \mathrm{DH}_{\mathrm{dec}}$ and $5 \% \mathrm{DH}_{\mathrm{dec}}$ (Figure $1 \mathrm{~d}-\mathrm{f}$ ). The median peptide molar weight of $3 \% \mathrm{DH}_{\mathrm{col}}$ was $4000 \mathrm{~g} \cdot \mathrm{mol}^{-1}$ (against $2300 \mathrm{~g} \cdot \mathrm{mol}^{-1}$ in $\left.3 \% \mathrm{DH}_{\mathrm{dec}}\right) .5 \% \mathrm{DH}_{\mathrm{col}}$ also showed a higher median peptide molar weight than $5 \% \mathrm{DH}_{\mathrm{dec}}$ for an NKT purity very close to the corresponding decolorized hydrolysates (around 25 $\mathrm{mg} \cdot \mathrm{g}^{-1}$ at $3 \% \mathrm{DH}$ and $45 \mathrm{mg} \cdot \mathrm{g}^{-1}$ at $5 \% \mathrm{DH}$, Figure $1 \mathrm{f}$ ). This is probably due to a loss of large-molar-weight peptides occurring during the decoloration procedure. Indeed, large peptides are known to be associated with haem at low DH by a complex system of peptide - peptide and peptide-haem interactions [10]. This resulted a large amount in peptides with a larger molecular size than NKT $(99 \%)$ in $3 \% \mathrm{DH}_{\text {col }}$ hydrolysate. Hence, an outstanding enrichment of NKT by ultrafiltration should be expected.

To summarize, the lower the DH was, the more hydrolysates are rich in large peptides, allowing for very high enrichment by UF. However, the higher the DH was, the higher the 
starting NKT purity was. Hence, each hydrolysate must be considered in the UF fractionation study for the NKT separation. From the hydrolysate molar weight distributions, it is reasonable to expect an interesting NKT purity in the permeate compartment of the 1 or $3 \mathrm{~kg} \cdot \mathrm{mol}^{-1}$ membranes.

\subsection{NKT Enrichement by Ultrafiltration}

A simulation methodology to predict the NKT enrichment and yield with the 1 and $3 \mathrm{~kg} \cdot \mathrm{mol}^{-1}$ membranes was used to avoid a time- and cost-consuming full experimental approach. This method only requires (i) a membrane calibration based on the SEC analysis of permeate and retentate in full recycling mode (both permeate and retentate outlets) and (ii) a SEC analysis of the hydrolysate [21].

\subsubsection{Membrane Calibrations}

The calibrations of the 1 and $3 \mathrm{~kg} \cdot \mathrm{mol}^{-1}$ (MWCO) regenerated cellulose membranes obtained with each hydrolysate according to Kapel et al. [27] are presented in Figure 2. The calibration curves were reliably regressed by a linear model $\left(0.995>R^{2}>0.988\right)$. Whatever the $\mathrm{DH}$, the hydrolysates with or without haem showed very similar trends on both 1 and $3 \mathrm{~kg} \cdot \mathrm{mol}^{-1} \mathrm{MWCO}$ membranes. This indicated that the peptide transport was mainly driven by phenomena related to steric hindrance. Hydrophobic interactions were shown to be responsible for peptide-membrane interactions [29] with PES and PS membranes. These interactions impacted peptide transmissions [30]. It is well known that the reduction in peptide size by proteolysis sensibly reduces the overall hydrophobicity pattern of the hydrolysate. Hence, a modification of the calibration should have been expected with the different DH hydrolysates. The poor effect observed here is probably due to the high hydrophilicity of the regenerated cellulose membranes surface [31] that reduces potential hydrophobic interactions with the membrane surface. The similarity observed between the different calibration curves showed that only one can be chosen for the following simulation calculations. This is particularly interesting because it shows that the membrane calibration obtained with a protein hydrolysate can be applied to any other hydrolysate from the same protein (with different DH). These results confirmed the theoretical reliability of this simulation methodology.

a

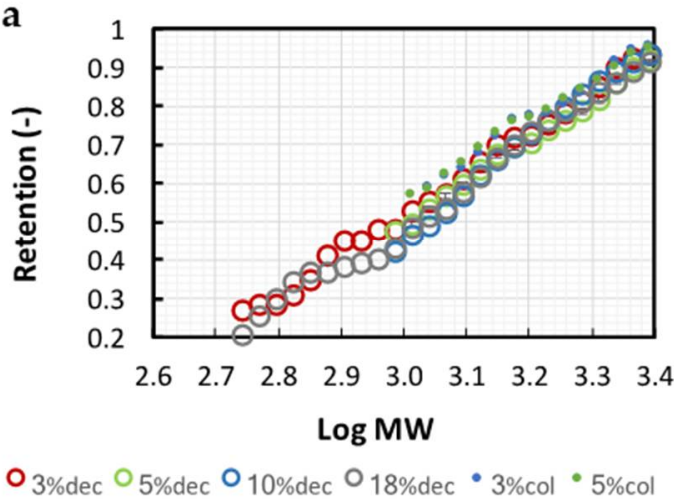

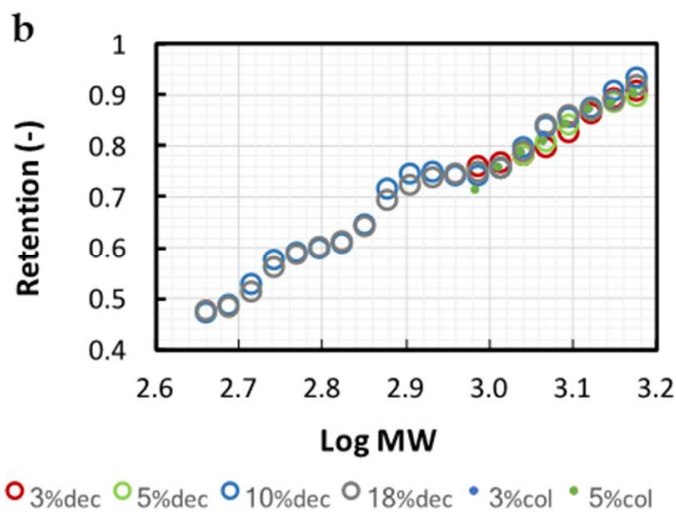

Figure 2. 3 and $1 \mathrm{~kg} \cdot \mathrm{mol}^{-1} \mathrm{MWCO}$ membrane calibration curves (respectively (a,b)) obtained with decolored 3\%, 5\%, $10 \%$ and $18 \% \mathrm{DH}(\mathrm{dec})$ and colored $3 \%$ and $5 \% \mathrm{DH}(\mathrm{col})$ hydrolysates. Retention versus log (MW) curves were built from permeate and retentate size exclusion chromatograms in total recirculation mode.

As expected, the peptide transmission was higher for the $3 \mathrm{~kg} \cdot \mathrm{mol}^{-1}$ membrane (retention of 0.5 for peptides of $1000 \mathrm{~g} \cdot \mathrm{mol}^{-1}$ against 0.78 with $1 \mathrm{~kg} \cdot \mathrm{mol}^{-1}$ membrane). The apparent MWCO (defined as the molar weight of a peptide retained at $90 \%$ ) for bHb peptides differed from the given MWCO (1445 vs. $1000 \mathrm{~g} \cdot \mathrm{mol}^{-1}$ and $\left.2510 \mathrm{vs} .3000 \mathrm{~g} \cdot \mathrm{mol}^{-1}\right)$. Chabeaud et al. [20] also observed this phenomenon with a PES membrane $\left(4 \mathrm{~kg} \cdot \mathrm{mol}^{-1}\right)$ using a fish protein hydrolysate. This can be explained by the fact that manufacturers establish 
membranes MWCO based on standards with shapes that are different from peptides. NKT retention $\left(\mathrm{R}_{\mathrm{NKT}}\right)$ was of 0.305 and 0.652 with the 1 and $3 \mathrm{~kg} \cdot \mathrm{mol}^{-1}$ membrane, respectively.

\subsubsection{NKT Yield, Enrichment, and Purity Simulation}

Figure 3 shows the predictions of the evolution of the NKT yield and enrichment in the 1 and $3 \mathrm{~kg} \cdot \mathrm{mol}^{-1}$ membrane permeates for each hydrolysate. With $1 \mathrm{~kg} \cdot \mathrm{mol}^{-1}$ permeate, the highest hydrolysate DH were, the lowest NKT enrichments were. At the early stage of the UF $(\mathrm{VRF}=1.1)$, the NKT enrichment values were 11.3, 4.6, 2.5 and 1.4 for decolored $3 \%$, $5 \%, 10 \%$ and $18 \% \mathrm{DH}_{\mathrm{dec}}$, respectively. This is due to a higher proportion of peptides having a molecular size smaller than the membrane cut-off in the hydrolysates with higher $\mathrm{DH}$. A larger fraction of peptides may, therefore, be transferred through the membrane with NKT. This was also observed in the reported work of Przybylski and coworkers [28] on NKT recovery by electrodialysis with ultrafiltration membranes (EDUF). The NKT enrichments remained constant during UF for $10 \%$ and $18 \% \mathrm{DH}_{\text {dec }}$ while a decrease was observed for $5 \%$ and $3 \% \mathrm{DH}_{\mathrm{dec}}$. The largest enrichment values were observed for $3 \%$ and $5 \% \mathrm{DH}_{\mathrm{col}}(27$ and 7.4 at VRF 1.1, respectively). For these two low DH hydrolysates, a decrease in NKT enrichment is also observed during the process.
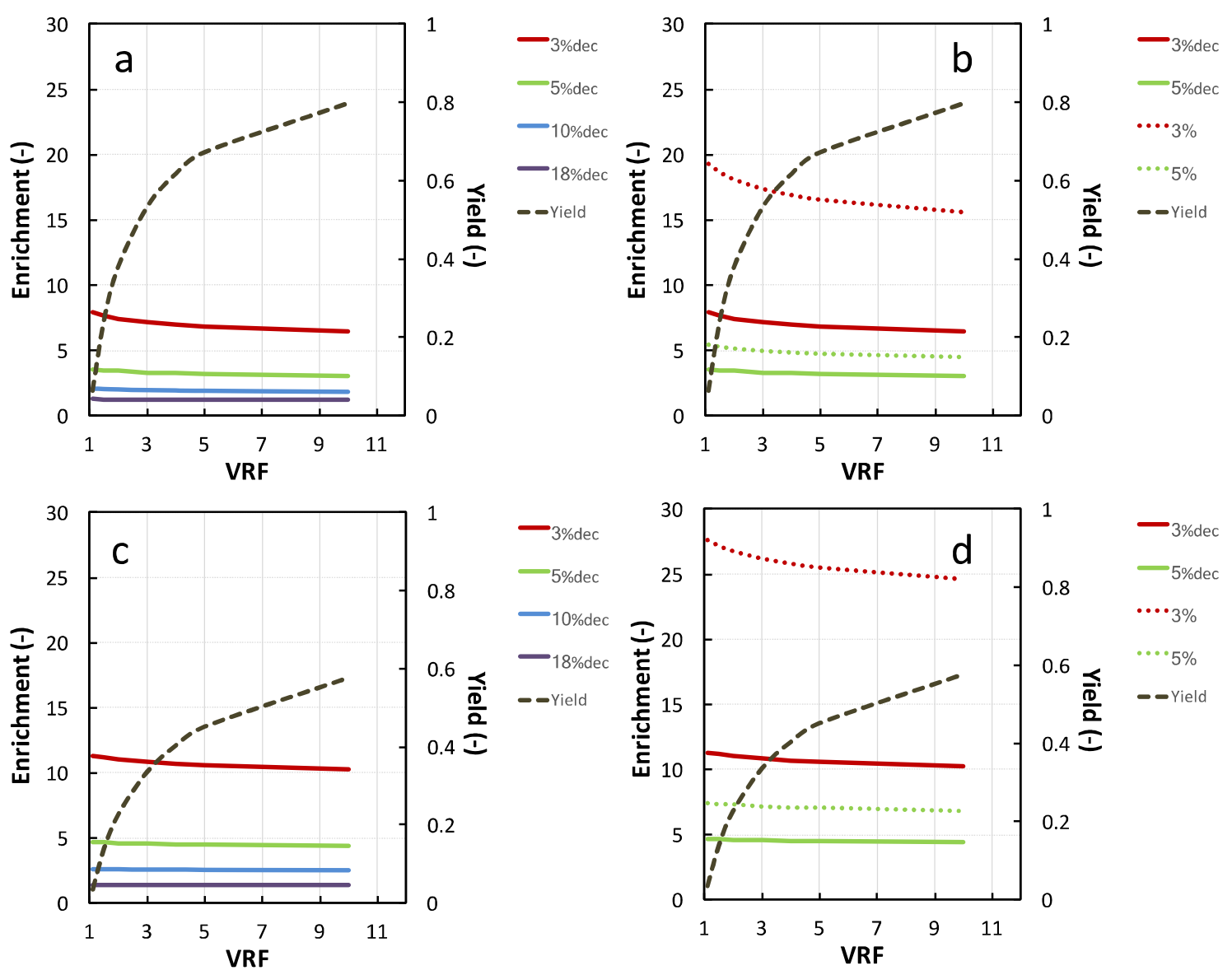

Figure 3. Calculated evolution of NKT yield and enrichment in the permeate compartment during the ultrafiltration of decolored $3 \%, 5 \%, 10 \%$ and $18 \% \mathrm{DH}(\mathbf{a}, \mathbf{c})$ and colored $3 \%$ and $5 \% \mathrm{DH}(\mathbf{b}, \mathbf{d})$ with the $3 \mathrm{~kg} \cdot \mathrm{mol}^{-1}$ membrane $(\mathbf{a}, \mathbf{b})$ and $1 \mathrm{~kg} \cdot \mathrm{mol}^{-1}$ membrane (c,d). Membrane calibration equations used for calculations were $\mathrm{R}=0.7978 \times \log (\mathrm{MW})-1.6206$ and $\mathrm{R}=1.0552 \times \log (\mathrm{MW})-2.666$ for 1 and $3 \mathrm{~kg} \cdot \mathrm{mol}^{-1}$, respectively.

With the $3 \mathrm{~kg} \cdot \mathrm{mol}^{-1}$ membrane, similar trends were observed, with lower enrichment values. The difference of NKT enrichment obtained with the two membranes was particularly marked with the low DH hydrolysates (with or without haem). Obviously, the strong discrepancies observed in NKT enrichments are due to the hydrolysate peptide 
molar weight distribution. Indeed, $18 \% \mathrm{DH}$ hydrolysate contained $60 \%$ of peptides with a retention close to NKT (from 0.5 to 0.8 for $1 \mathrm{~kg} \cdot \mathrm{mol}^{-1}$ and 0.15 to 0.45 for $3 \mathrm{~kg} \cdot \mathrm{mol}^{-1}$ membrane). As comparison, $90 \%$ of $3 \% \mathrm{DH}_{\text {col }}$ significantly had retentions higher than NKT ( 0.64 and 0.88 for $1 \mathrm{~kg} \cdot \mathrm{mol}^{-1}$ and $\left.3 \mathrm{~kg} \cdot \mathrm{mol}^{-1}\right)$. It can be noticed that the enrichment values obtained with $3 \% \mathrm{DH}_{\mathrm{col}}$ hydrolysate with both membranes (between 27 and 15) are outstanding for UF separation. As comparison, Przybylski and coworkers [28] observed no significant enrichment factor for the 3\%DH hydrolysate separation by EDUF and a maximal enrichment factor of about 13-fold (the same analytical methods as for NKT quantification). Kapel et al. [21] observed an enrichment value in an antihypertensive peptide of only 1.3 upon UF of an alfalfa white protein hydrolysate with a $1 \mathrm{~kg} \cdot \mathrm{mol}^{-1}$ regenerated cellulose membrane at VRF 3.

The NKT yield in the $1 \mathrm{~kg} \cdot \mathrm{mol}^{-1}$ permeate compartment increased quickly up to VRF 5 (0.47) and raised then more slowly to reach 0.60 at VRF 10 . The yields with $3 \mathrm{~kg} \cdot \mathrm{mol}^{-1}$ membrane followed the same pattern but showed higher values ( 0.65 at VRF 5 and 0.8 at VRF 10). As indicated by Equations (2) and (3), the peptide yield for a given VRF only depends on its retention value. Hence, the highest value of NKT retention with the $1 \mathrm{~kg} \cdot \mathrm{mol}^{-1}$ membrane than the $3 \mathrm{~kg} \cdot \mathrm{mol}^{-1}$ (0.652 vs. 0.305$)$ is responsible for the lower yields.

On the one hand, NKT yield increases with FRV. However, on the other hand, NKT enrichment for the low DH hydrolysates decreases with FRV. From simulations, the $1 \mathrm{~kg} \cdot \mathrm{mol}^{-1}$ permeate of $3 \% \mathrm{DHcol}$ hydrolysate would give the better enrichments. However, for a given FRV, the $3 \mathrm{~kg} \cdot \mathrm{mol}^{-1}$ membrane would show a far better yield. Besides, the $3 \mathrm{~kg} \cdot \mathrm{mol}^{-1}$ membrane would probably show a higher permeate flux. Hence, far better productivity should be expected from this last membrane. Since it is impossible to forecast the impact of the NKT enrichment or purity on the overall fraction antimicrobial activity, it was decided to implement the UF fractionation of this hydrolysate with both membranes and check the fraction bioactivity. A VRF 3 and 5 was chosen with the 3 and $1 \mathrm{~kg} \cdot \mathrm{mol}^{-1}$ membranes, respectively, to obtain the same yield value (near 50\%).

It is important for industrial application that the enriched product is free of haem due to its unsuitable dark color. A high removal of haem in $3 \% \mathrm{DH}_{\mathrm{col}}$ in the permeate of each membrane should be expected, since a full haem retention was observed upon ultrafiltration of a bHb hydrolysate at low $\mathrm{DH}$ with a $10 \mathrm{~kg} \cdot \mathrm{mol}^{-1}$ regenerated cellulose membrane [32]. However, in the case of partial haem removal, $3 \% \mathrm{DH}_{\mathrm{dec}}$ was also included in the study.

\subsection{Experimental Fractionation with $1 \mathrm{~kg} \cdot \mathrm{mol}^{-1}$ and $3 \mathrm{~kg} \cdot \mathrm{mol}^{-1}$ Membranes}

Figure 4 shows the evolution of the permeate flux during UF with the 1 and $3 \mathrm{~kg} \cdot \mathrm{mol}^{-1}$ membranes of the $3 \% \mathrm{DH}$ colored and decolored hydrolysates. The permeate fluxes observed were nine times superior with the $3 \mathrm{~kg} \cdot \mathrm{mol}^{-1}$ (Figure $4 \mathrm{~b}$ ) than with the $1 \mathrm{~kg} \cdot \mathrm{mol}^{-1}$ (Figure 4a) membrane. The figure also indicates that the flux remained rather stable during the fractionation. Eventually, it can be noticed that the presence of haem in the hydrolysate had no significant impact either on the permeate flux or the peptide transmission. 
a

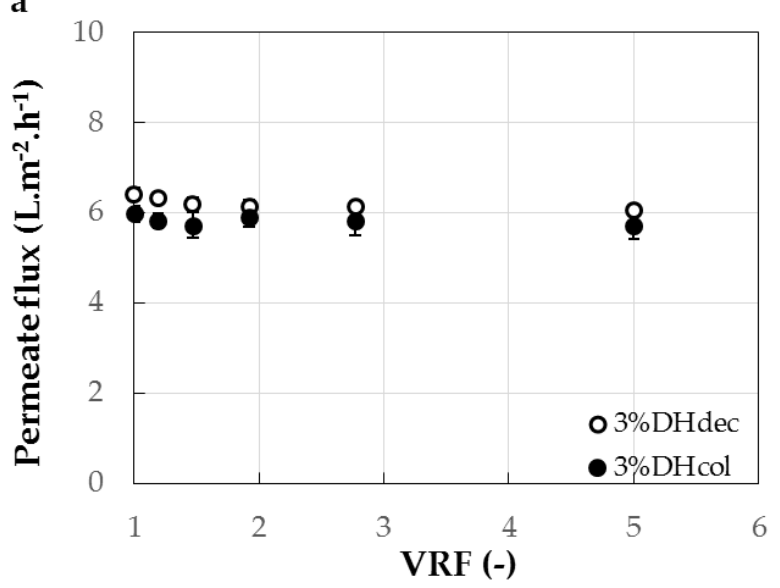

b

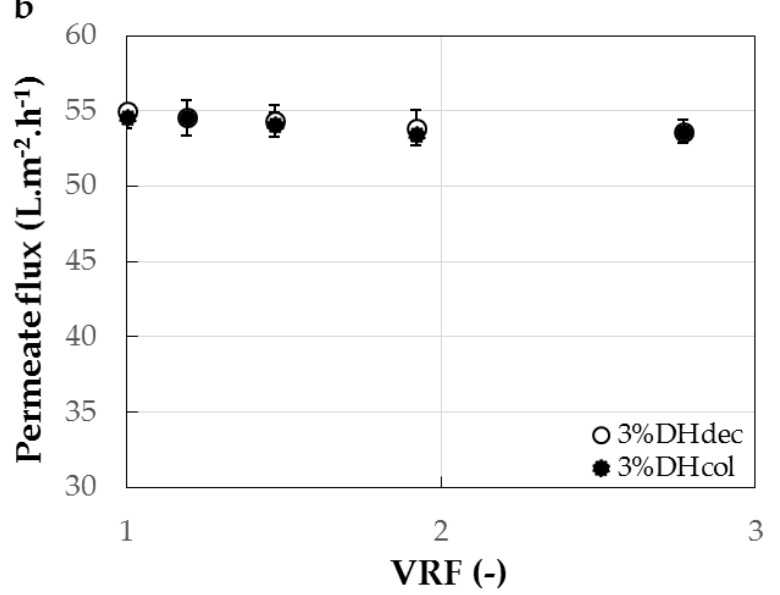

Figure 4. Evolution of the permeate flux during the ultrafiltration of decolored $3 \% \mathrm{DH}_{\mathrm{dec}}$ hydrolysate and colored $3 \% \mathrm{DH}$ hydrolysate with the $1 \mathrm{~kg} \cdot \mathrm{mol}^{-1}(\mathbf{a})$ and $3 \mathrm{~kg} \cdot \mathrm{mol}^{-1}(\mathbf{b})$ membrane cut-offs (surface of $88 \mathrm{~cm}^{2}$ ) to a volume reduction factor (VRF) of 5 and 3, respectively.

Table 1 shows the experimental NKT yields, purities and enrichments obtained during UF with the 1 and $3 \mathrm{~kg} \cdot \mathrm{mol}^{-1}$ membranes of the $3 \%$ DH colored and decolored hydrolysates. The experimental values were compared with the calculated values obtained from the simulation methodology. The fraction productivity (expressed in $\mathrm{g} \cdot \mathrm{m}^{-2} \cdot \mathrm{h}^{-1}$ ) deduced from the process duration is also shown in this table. The table indicated that the relative errors between calculation and experiments were between 2 and 13\%. This demonstrated the high accuracy of the simulation methodology described by Kapel et al. [21] with another type of hydrolysate.

Table 1. Calculated NKT enrichment (-), yield (\%), and purity (\%) for colored and decolored $3 \% \mathrm{DH}$ hydrolysates in the permeate compartment at VRF 3 and 5 for 3 and $1 \mathrm{~kg} \cdot \mathrm{mol}^{-1}$ membranes, respectively and experimental NKT enrichment (-), yield (\%), purity (\%) and fraction productivity $\left(\mathrm{g} \cdot \mathrm{m}^{-2} \cdot \mathrm{h}^{-1}\right)$. Experimental values are the means of two experimentations and relative errors between them were less than $5 \%$.

\begin{tabular}{|c|c|c|c|c|}
\hline Molecular Weight & \multicolumn{2}{|c|}{$1 \mathrm{~kg} \cdot \mathrm{mol}^{-1}$ Permeate } & \multicolumn{2}{|c|}{$3 \mathrm{~kg} \cdot \mathrm{mol}^{-1}$ Permeate } \\
\hline $\begin{array}{l}\text { Colored or decolored } \\
\text { hydrolysate }(3 \% \mathrm{DH})\end{array}$ & Decolored & Colored & Decolored & Colored \\
\hline Initial NKT purity (\%) & 2.6 & 2.5 & 2.6 & 2.5 \\
\hline Calc. NKT Enrich. (-) & 10.7 & 25.5 & 7.2 & 17.4 \\
\hline Exp. NKT Enrich. (-) & 9.7 & 28.7 & 6.8 & 15.7 \\
\hline Calc. NKT purity (\%) & 27.9 & 62.5 & 18.8 & 42.6 \\
\hline Exp. NKT purity (\%) & 25.3 & 70.3 & 17.7 & 38.5 \\
\hline Calc. NKT Yield. (\%) & 46 & 46 & 54 & 54 \\
\hline Exp. NKT Yield. (\%) & 52 & 44 & 55 & 55 \\
\hline Exp. productivity & 1.2 & 0.5 & 21.2 & 9.8 \\
\hline$\left(\mathrm{g} \cdot \mathrm{m}^{-2} \cdot \mathrm{h}^{-1}\right)$ & & & & \\
\hline
\end{tabular}

Table 1 also shows that the experimental purities obtained with $3 \% \mathrm{DH}_{\mathrm{col}}$ and both membranes were two times higher than the purities obtained with $3 \% \mathrm{DH}_{\mathrm{dec}}$. For $3 \% \mathrm{DH}_{\mathrm{col}}$, remarkably high NKT purities were observed in the UF permeates $(70.3 \%$ and $38.5 \%$ with the 1 and $3 \mathrm{~kg} \cdot \mathrm{mol}^{-1}$ membranes, respectively). It is very notable that such purity was reached using an ultrafiltration process with a similarly complex starting mixture. As a comparison, the best purity observed for the NKT selective separation by EDUF was 10.3\% at $5 \% \mathrm{DH}_{\mathrm{dec}}$ [28]. In general, higher productivity was observed with $3 \% \mathrm{DH}_{\mathrm{dec}}$ as compared to $3 \% \mathrm{DH}_{\mathrm{col}}$. This is because the total peptide transmission was higher with this hydrolysate, 
while the permeate fluxes remained the same. However, the productivity observed with $3 \% \mathrm{DH}_{\text {col }}$ and the $3 \mathrm{~kg} \cdot \mathrm{mol}^{-1}$ membrane $\left(9.8 \mathrm{~g} \cdot \mathrm{m}^{-2} \cdot \mathrm{h}^{-1}\right)$ was higher than the reported transport rate value with EDUF implementation $\left(0.67 \mathrm{~g} . \mathrm{m}^{-2} \cdot \mathrm{h}^{-1} ;[28]\right)$. These productivity values are also noteworthy for an ultrafiltration process of such a complex mixture. Taken as a whole, the UF of the $3 \% \mathrm{DH}_{\mathrm{col}}$ with both membranes offered great performances either regarding the NKT purity or the fraction productivity. Figure 5 shows the RP-HPLC profiles of this hydrolysate, the $1 \mathrm{~kg} \cdot \mathrm{mol}^{-1}$ permeate, and the $3 \mathrm{~kg} \cdot \mathrm{mol}^{-1}$ permeate. $3 \% \mathrm{DH}_{\mathrm{col}}$ showed an important peptide population containing high-molecular-weight peptides at retention times from 25 to $38 \mathrm{~min}$. This population was globally hydrophobic. Some peptide peaks were observed from 3 to $20 \mathrm{~min}$, representing small peptides that were less hydrophobic than those at high retention times. The peak corresponding to NKT was observed between 2 and $3 \mathrm{~min}$ and its weak area showed a low proportion in the total hydrolysate. The higher peak at $39 \mathrm{~min}$ was the haem. The undigested hemoglobin subunits were present from 40 to $60 \mathrm{~min}$, meaning that the hemoglobin protein was not fully hydrolyzed by pepsin at this DH value. For the $1 \mathrm{~kg} \cdot \mathrm{mol}^{-1}$ permeate, the major peptide population was observed for retention times from 25 to $35 \mathrm{~min}$ and the undigested hemoglobin subunits were not present due to their high molecular weight (higher than $15 \mathrm{kDa}$ ). However, fewer peptides were present in this fraction compared to the whole hydrolysate due to the lower number of peaks. At around the $3 \mathrm{~kg} \cdot \mathrm{mol}^{-1}$ permeate, the same tendency was observed, but the peptide population was more important. Indeed, the number of peaks was more important, and their intensities were higher than with the $1 \mathrm{~kg} \cdot \mathrm{mol}^{-1}$ membrane. Furthermore, the NKT enrichment was better for the $1 \mathrm{~kg} \cdot \mathrm{mol}^{-1}$ permeate with a higher NKT peak observed at 3 min compared to the whole hydrolysate. Hence, the $1 \mathrm{~kg} \cdot \mathrm{mol}^{-1}$ permeate allowed a better NKT enrichment and purity, which is in accordance with the results presented above. Finally, the disappearance of the haem peak (39 $\mathrm{min}$ ) on the RP-HPLC profiles of the $1 \mathrm{~kg} \cdot \mathrm{mol}^{-1}$ permeate and the $3 \mathrm{~kg} \cdot \mathrm{mol}^{-1}$ permeate proved that the 1 and $3 \mathrm{~kg} \cdot \mathrm{mol}^{-1}$ regenerated cellulose membranes can also retain the haem during the UF of bHb hydrolysates.

\subsection{Evaluation of Peptide Fraction Antimicrobial Activity}

The minimal inhibitory concentrations $\left(\mu \mathrm{g}_{\text {peptides }} \cdot \mathrm{mL}^{-1}\right.$ ) for the $\mathrm{bHb}$ hydrolysate $\left(3 \% \mathrm{DH}_{\mathrm{col}}\right)$ against the peptide fractions obtained in the permeate compartment after UF with the 1 and $3 \mathrm{~kg} \cdot \mathrm{mol}^{-1}$ membranes were presented in Table 2 . The permeates obtained from the colored hydrolysate $\left(3 \% \mathrm{DH}_{\mathrm{col}}\right)$ with both membranes showed significant differences in terms of antimicrobial activities compared to the initial hydrolysate. This fact indicated that the antimicrobial activity of the peptide fractions was most efficient after UF separation. These results were in accordance with the NKT enrichment factors observed previously in the samples. 

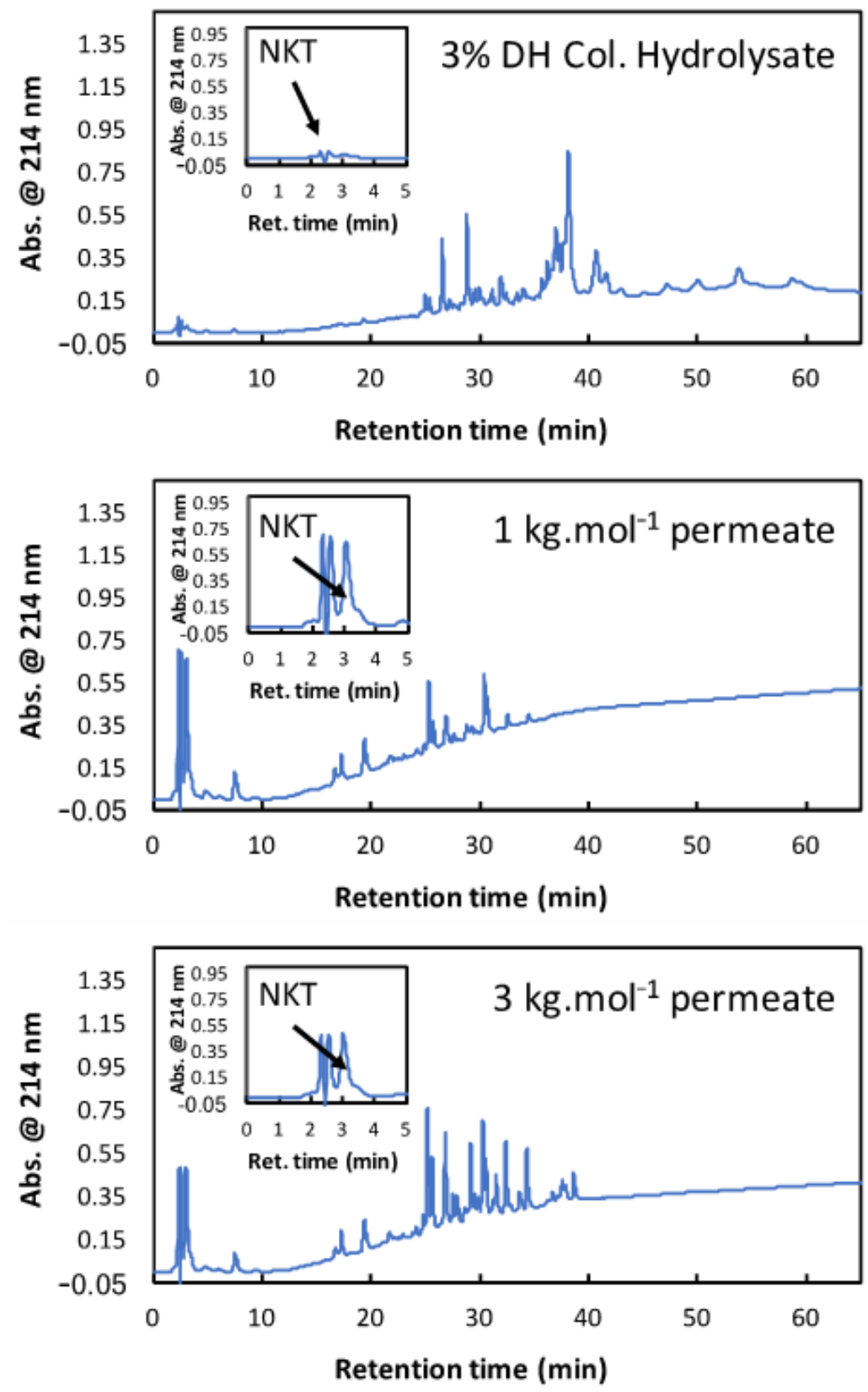

Figure 5. Reverse Phase-HPLC profiles of colored bovine hemoglobin hydrolysate at 3\%DH and the permeate of this hydrolysate obtained with $1 \mathrm{~kg} \cdot \mathrm{mol}^{-1}$ and $3 \mathrm{~kg} \cdot \mathrm{mol}^{-1}$ membrane cut-offs.

Table 2. Minimal inhibitory concentrations $\left(\mu \mathrm{g}_{\text {peptides }} \cdot \mathrm{mL}^{-1}\right)$ for standard NKT and bovine hemoglobin hydrolysate $\left(3 \% \mathrm{DH}_{\mathrm{col}}\right)$ against peptide fractions obtained in the permeate compartment after ultrafiltration separation with 1 and 3 $\mathrm{kg} \cdot \mathrm{mol}^{-1}$ membrane cut-offs.

\begin{tabular}{ccccccc}
\hline \multirow{2}{*}{ Sample } & $\begin{array}{c}\text { Colored or } \\
\text { Decolored } \\
\text { Hydrolysate } \\
\mathbf{( 3 \% D H )}\end{array}$ & $\begin{array}{c}\text { Molecular } \\
\text { Weight Cut-off }\end{array}$ & $\begin{array}{c}\text { Microccocus } \\
\text { luteus } \\
\text { ATCC 4698 }\end{array}$ & $\begin{array}{c}\text { Listeria } \\
\text { innocua } \\
\text { ATCC 33090 }\end{array}$ & $\begin{array}{c}\text { Escherichia } \\
\text { coli } \\
\text { ATCC 25922 }\end{array}$ & $\begin{array}{c}\text { Salmonella } \\
\text { enteretidis } \\
\text { ATCC 13076 }\end{array}$ \\
\hline NKT & Standard & $/$ & $5.85^{*}$ & $0.65 *$ & $5.85^{*}$ & $3.25^{*}$ \\
\hline Hydrolysate & Colored & $/$ & $256.2 \pm 0.00$ & $128.1 \pm 0.00$ & $53.38 \pm 15.1$ & $128.1 \pm 0.00$ \\
\hline Permeate & Colored & $1 \mathrm{~kg} \cdot \mathrm{mol}^{-1}$ & $2.06 \pm 0.00$ & $16.43 \pm 0.00$ & $8.21 \pm 0.00$ & $8.21 \pm 0.00$ \\
\hline Permeate & Colored & $3 \mathrm{~kg} \cdot \mathrm{mol}^{-1}$ & $47.93 \pm 0.00$ & $39.94 \pm 11.3$ & $5.99 \pm 0.00$ & $9.98 \pm 1.50$ \\
\hline
\end{tabular}

* CMI values calculated from previous study [5] and expressed in $\mu \mathrm{g}$ peptides $\cdot \mathrm{mL}^{-1}$. 
The $1 \mathrm{~kg} \cdot \mathrm{mol}^{-1}$ permeate obtained peptide fractions with a low MIC (under 20 $\mu g_{\text {peptides }} \cdot \mathrm{mL}^{-1}$ against all tested strains), indicating a strong antimicrobial activity for all tested strains compared to the initial hydrolysate (MIC values from $53.38 \pm 15.1$ $\mu g_{\text {peptides }} \cdot \mathrm{mL}^{-1}$ against Escherichia coli to $256.2 \mu \mathrm{g}_{\text {peptides }} \cdot \mathrm{mL}^{-1}$ against Microccocus $l u$ teus). Using the $3 \mathrm{~kg} \cdot \mathrm{mol}^{-1} \mathrm{MWCO}$ membrane, the MIC values were higher than using the $1 \mathrm{~kg} \cdot \mathrm{mol}^{-1} \mathrm{MWCO}$ membrane against Microccocus luteus $\left(47.93 \mu \mathrm{g}_{\text {peptides }} \cdot \mathrm{mL}^{-1}\right.$ for the $3 \mathrm{~kg} \cdot \mathrm{mol}^{-1}$ permeate and $2.06 \mathrm{for}$ the $\left.1 \mathrm{~kg} \cdot \mathrm{mol}^{-1}\right)$ and Listeria innocua $(39.94 \pm 11.3$ $\mu \mathrm{g}_{\text {peptides }} \cdot \mathrm{mL}^{-1}$ and $16.43 \mu \mathrm{g}_{\text {peptides }} \cdot \mathrm{mL}^{-1}$ for the $1 \mathrm{~kg} \cdot \mathrm{mol}^{-1}$ ). The lower MIC obtained with the $1 \mathrm{~kg} \cdot \mathrm{mol}^{-1} \mathrm{MWCO}$ membrane showed that fewer peptides were recovered in the permeate, corresponding to a better enrichment in NKT, as observed previously (28.7 against 15.7 with the $3 \mathrm{~kg} \cdot \mathrm{mol}^{-1} \mathrm{MWCO}$ membrane). The MIC values remained in the same range against Escherichia coli (8.21 and $5.99 \mu \mathrm{g}_{\text {peptides }} \cdot \mathrm{mL}^{-1}$ for the 1 and $3 \mathrm{~kg} \cdot \mathrm{mol}^{-1}$, respectively) and Salmonella enteretidis (8.21 and $9.98 \pm 1.50 \mu \mathrm{g}_{\text {peptides }} \cdot \mathrm{mL}^{-1}$ for the 1 and $3 \mathrm{~kg} \cdot \mathrm{mol}^{-1}$, respectively).

The most striking fact was that the $1 \mathrm{~kg} \cdot \mathrm{mol}^{-1}$ permeate from the $3 \% \mathrm{DH}_{\text {col }}$ hydrolysate had an activity close to the standard NKT. From these results, it can be said that the antimicrobial activity was in relation with the process selectivity and the NKT purity. Indeed, using a $3 \mathrm{~kg} \cdot \mathrm{mol}^{-1} \mathrm{MWCO}$ membrane showed peptide fractions that were less enriched in NKT with an antimicrobial activity that was less effective than when using a $1 \mathrm{~kg} \cdot \mathrm{mol}^{-1} \mathrm{MWCO}$ membrane. This could be explained by the presence in the $3 \mathrm{~kg} \cdot \mathrm{mol}^{-1}$ permeate of more peptides (Figure 5), including in the group S1 of antimicrobial peptides [2]. This kind of peptide was less effective than the peptides of group S2 as NKT. Their presence decreased the NKT purity and, consequently, the bioactivity of the peptide fraction from UF permeates.

\section{Conclusions}

In this study, a simulation method was applied to predict the enrichment rate, extraction yield and purity of an antimicrobial peptide (NKT) in various bovine hemoglobin hydrolysates during ultrafiltration. It has been observed that the NKT enrichment decreased while the DH of the hydrolysate increased. From the prediction results, the most promising hydrolysates were identified (the colored and decolored 3\%DH hydrolysates) and the experimental ultrafiltration conditions were rationally implemented for higher antimicrobial recovery. A remarkably high experimental NKT purity of about 70\%, corresponding to an enrichment factor of about 29, compared to the initial hydrolysate, was obtained for the ultrafiltration of the colored $3 \% \mathrm{DH}$ hydrolysate with the $1 \mathrm{~kg} \cdot \mathrm{mol}^{-1}$ MWCO-regenerated cellulose membrane at a VRF of 5. These results are noteworthy for a tangential ultrafiltration process of such a complex mixture. The permeate thus obtained showed excellent antimicrobial activity close to the standard NKT, demonstrating its promising potential use in food safety. Finally, the comparison of the experimental and simulated data demonstrated that the simulation methodology was valid with another case and proved its high reliability and utility.

Author Contributions: Conceptualization, R.P., N.N., P.D. and R.K.; methodology, S.B., A.B., P.D. and R.K.; software, S.B., R.P., A.B.; validation, R.P., A.B., P.D. and R.K.; formal analysis, R.P. and A.B.; investigation, S.B., R.P. and A.B.; resources, N.N., P.D. and R.K.; data curation, S.B., R.P., A.B. and R.K.; writing-original draft preparation, R.P., A.B. and R.K.; writing-review and editing, S.B., R.P. and R.K.; visualization, S.B., R.P., P.D. and R.K.; supervision, N.N., P.D. and R.K.; project administration, N.N., P.D. and R.K.; funding acquisition, N.N., P.D. and R.K. All authors have read and agreed to the published version of the manuscript.

Funding: This research received no external funding.

Conflicts of Interest: The authors declare no conflict of interest. The funders had no role in the design of the study; in the collection, analyses, or interpretation of data; in the writing of the manuscript, or in the decision to publish the results. 


\section{References}

1. Lynch, S.A.; Mullen, A.M.; O’Neill, E.E.; García, C.Á. Harnessing the potential of blood proteins as functional ingredients: A review of the state of the art in blood processing. Compr. Rev. Food Sci. Food Saf. 2017, 16, 330-344. [CrossRef] [PubMed]

2. Nedjar-Arroume, N.; Dubois-Delval, V.; Adje, E.Y.; Traisnel, J.; Krier, F.; Mary, P.; Guillochon, D. Bovine hemoglobin: An attractive source of antibacterial peptides. Peptides 2008, 29, 969-977. [CrossRef] [PubMed]

3. Powers, J.P.S.; Hancock, R.E. The relationship between peptide structure and antibacterial activity. Peptides 2003, 24, 1681-1691. [CrossRef] [PubMed]

4. Lopes, S.C.; Fedorov, A.; Castanho, M.A. Lipidic membranes are potential "catalysts" in the ligand activity of the multifunctional pentapeptide neokyotorphin. Chembiochem 2005, 6, 697-702. [CrossRef] [PubMed]

5. Catiau, L.; Traisnel, J.; Delval-Dubois, V.; Chihib, N.E.; Guillochon, D.; Nedjar-Arroume, N. Minimal antimicrobial peptidic sequence from hemoglobin alpha-chain: KYR. Peptides 2011, 32, 633-638. [CrossRef]

6. Przybylski, R.; Firdaous, L.; Châtaigné, G.; Dhulster, P.; Nedjar, N. Production of an antimicrobial peptide derived from slaughterhouse by-product and its potential application on meat as preservative. Food Chem. 2016, 211, 306-313. [CrossRef]

7. Vanhoute, M.; Firdaous, L.; Bazinet, L.; Froidevaux, R.; Lecouturier, D.; Guillochon, D.; Dhulster, P. Effect of haem on the fractionation of bovine haemoglobin peptic hydrolysate by electrodialysis with ultrafiltration membranes. J. Membr. Sci. 2010, 365, 16-24. [CrossRef]

8. Aubes-Dafau, I.; Capdevielle, J.; Seris, J.L.; Combes, D. Bitter peptide from hemoglobin hydrolysate: Isolation and characterization. FEBS Lett. 1995, 364, 115-119.

9. Dhulster, P.; Kapel, R.; Froidevaux, R.; Nedjar-Arroume, N.; Fertin-Bazus, A.; Choisnard, L.; Guillochon, D. Advancement in intermediate opioid peptide production in an enzymatic membrane reactor assisted by solvent extraction. Desalination 2002, 148, 221-226. [CrossRef]

10. Lebrun, F.; Bazus, A.; Dhulster, P.; Guillochon, D. Influence of molecular interactions on ultrafiltration of a bovine hemoglobin hydrolysate with an organic membrane. J. Membr. Sci. 1998, 146, 113-124. [CrossRef]

11. Agyei, D.; Ongkudon, C.M.; Wei, C.Y.; Chan, A.S.; Danquah, M.K. Bioprocess challenges to the isolation and purification of bioactive peptides. Food Bioprod. Process. 2016, 98, 244-256. [CrossRef]

12. He, R.; Girgih, A.T.; Malomo, S.A.; Ju, X.; Aluko, R.E. Antioxidant activities of enzymatic rapeseed protein hydrolysates and the membrane ultrafiltration fractions. J. Funct. Foods 2013, 5, 219-227. [CrossRef]

13. Onuh, J.O.; Girgih, A.T.; Aluko, R.E.; Aliani, M. In vitro antioxidant properties of chicken skin enzymatic protein hydrolysates and membrane fractions. Food Chem. 2014, 150, 366-373. [CrossRef] [PubMed]

14. Picot, L.; Ravallec, R.; Fouchereau-Péron, M.; Vandanjon, L.; Jaouen, P.; Chaplain-Derouiniot, M.; Bergé, J.P. Impact of ultrafiltration and nanofiltration of an industrial fish protein hydrolysate on its bioactive properties. J. Sci. Food Agric. 2010, 90, 1819-1826. [CrossRef]

15. Ranamukhaarachchi, S.; Meissner, L.; Moresoli, C. Production of antioxidant soy protein hydrolysates by sequential ultrafiltration and nanofiltration. J. Membr. Sci. 2013, 429, 81-87. [CrossRef]

16. Saidi, S.; Deratani, A.; Belleville, M.P.; Amar, R.B. Production and fractionation of tuna by-product protein hydrolysate by ultrafiltration and nanofiltration: Impact on interesting peptides fractions and nutritional properties. Food Res. Int. 2014, 65, 453-461. [CrossRef]

17. Wang, J.; Zhao, M.; Yang, X.; Jiang, Y. Improvement on functional properties of wheat gluten by enzymatic hydrolysis and ultrafiltration. J. Cereal Sci. 2006, 44, 93-100. [CrossRef]

18. Yu, G.C.; Li, J.T.; He, H.U.I.; Huang, W.h.; Zhang, W.J. Ultrafiltration preparation of potent bioactive corn peptide as alcohol metabolism stimulator in vivo and study on its mechanism of action. J. Food Biochem. 2013, 37, 161-167. [CrossRef]

19. Bourseau, P.; Vandanjon, L.; Jaouen, P.; Chaplain-Derouiniot, M.; Masse, A.; Guérard, F.; Berge, J.P. Fractionation of fish protein hydrolysates by ultrafiltration and nanofiltration: Impact on peptidic populations. Desalination 2009, 244, 303-320. [CrossRef]

20. Chabeaud, A.; Vandanjon, L.; Bourseau, P.; Jaouen, P.; Chaplain-Derouiniot, M.; Guérard, F. Performances of ultrafiltration membranes for fractionating a fish protein hydrolysate: Application to the refining of bioactive peptidic fractions. Sep. Purif. Technol. 2009, 66, 463-471. [CrossRef]

21. Kapel, R.; Klingenberg, F.; Framboisier, X.; Dhulster, P.; Marc, I. An original use of size exclusion-HPLC for predicting the performances of batch ultrafiltration implemented to enrich a complex protein hydrolysate in a targeted bioactive peptide. $J$. Membr. Sci. 2011, 383, 26-34. [CrossRef]

22. Wh, C.; Ji, M.; Fw, F. Standardizing a method for clinical hemoglobinometry. US Armed Forces Med. J. 1954, 5, $693-703$.

23. Church, F.C.; Porter, D.h.; Catignani, G.L.; Swaisgood, H.E. An o-phthalaldehyde spectrophotometric assay for proteinases. Anal. Biochem. 1985, 146, 343-348. [CrossRef]

24. Bodin, A.; Framboisier, X.; Alonso, D.; Marc, I.; Kapel, R. Size-exclusion HPLC as a sensitive and calibrationless method for complex peptide mixtures quantification. J. Chromatogr. B 2015, 1006, 71-79. [CrossRef]

25. Sila, A.; Hedhili, K.; Przybylski, R.; Ellouz-Chaabouni, S.; Dhulster, P.; Bougatef, A.; Nedjar-Arroume, N. Antibacterial activity of new peptides from barbel protein hydrolysates and mode of action via a membrane damage mechanism against Listeria monocytogenes. J. Funct. Foods 2014, 11, 322-329. [CrossRef]

26. Dubois, V.; Nedjar-Arroume, N.; Guillochon, D. Influence of $\mathrm{pH}$ on the appearance of active peptides in the course of peptic hydrolysis of bovine haemoglobin. Prep. Biochem. Biotechnol. 2005, 35, 85-102. [CrossRef] 
27. Linderstrom-Lang, K. The initial phases of the enzymatic degradation of proteins. Bull. Société Chim. Biol. 1953, 35, 100-116.

28. Przybylski, R.; Bazinet, L.; Kouach, M.; Goossens, J.F.; Dhulster, P.; Firdaous, L.; Nedjar-Arroume, N. Slaughterhouse By-Product Valorization: Hydrolysis Degree Modification for Higher Antimicrobial Recovery by Electroseparation. Waste Biomass Valorization 2020, 1-13. [CrossRef]

29. Gourley, L.; Gauthie, S.F.; Pouliot, Y.; Mollé, D.; Léonil, J.; Maubois, J.L. Identification of casein peptides interacting with polysulfone ultrafiltration membranes. Le Lait 1998, 78, 633-646. [CrossRef]

30. Bouhallab, S.; Henry, G. Transmission of a hydrophobic peptide through an inorganic ultrafiltration membrane: Effect of membrane support. J. Membr. Sci. 1995, 104, 73-79. [CrossRef]

31. Saidi, S.; Deratani, A.; Amar, R.B.; Belleville, M.P. Fractionation of a tuna dark muscle hydrolysate by a two-step membrane process. Sep. Purif. Technol. 2013, 108, 28-36. [CrossRef]

32. Kapel, R.; Froidevaux, R.; Nedjar-Arroume, N.; Fertin-Bazus, A.; Dhulster, P.; Guillochon, D. Continuous production of a peptidic fraction containing the intermediate opioid peptide LVV-haemorphin-7 (LVVh-7) by peptic hydrolysis of bovine haemoglobin in a continuous membrane reactor. Biotechnol. Appl. Biochem. 2003, 37, 317-324. [CrossRef] [PubMed] 